\title{
Maja Šabec
}

\section{Mit in pogled}

Mit je eden osrednjih pojavov $\mathrm{v}$ zgodovini človeštva - je najstarejši način osmišljanja resničnosti in primarni model vsake kulture, zato je razumljivo, da se vse oblike kulture nenehno obračajo in vračajo k izvoru podob v mitologiji, jih prevzemajo, presprašujejo in nadgrajujejo. Tokratna tematska številka, Mit in pogled, je zamišljena kot interdisciplinarno vozlišče raziskovalnih izzivov, v katerem vsak prispevek posebej in vsi skupaj podkrepljujejo vseprisotnost mitološke podstati, ki pomaga sodobnemu človeku najti odgovore na aktualna, v svojem bistvu pa vselej ponavljajoča se vprašanja. Združuje najraznovrstnejše raziskovalne pristope in metodologije, ki z odprtim in občutljivim sodobnim branjem univerzalnih in nacionalnih mitov ter s soočanjem dediščine in sodobnosti presegajo zgolj beleženje ali obujanje mitoloških motivov in z razkrivanjem poti, ki so jo miti prehodili od izvorne pripovedi do neločljivih plasti človekovega zavednega in nezavednega, spodbujajo možnosti vselej novih reinterpretacij.

Za rdečo nit pri tem pri poglabljanju v mitološko tematiko smo izbrali vlogo pogleda kot sprožilca usodnega preobrata: pogled lahko vabi, očara, osvobaja, pa tudi uroči, zavaja in ubije, lahko je neposreden ali skrit, vsemogočen ali prepovedan, pomnožen ali onemogočen. Najbolj tvoren od vseh pa je gotovo tisti, ki se srečuje z drugimi pogledi in jih odseva. Poskušali smo prestreči čim več teh srečanj in odsevov.

Zbrani prispevki predstavljajo enega od izsekov dvoletnega dinamičnega in kreativnega prepleta umetniških praks in teoretskih raziskovanj v okviru evropskega kulturnega projekta Crossing Stages. Gre za pionirski projekt, »delo v nastajanju«, v katerem sodelujejo ustvarjalci in teoretiki iz sedmih držav - Španije, Francije, Italije, Turčije, Danske, Portugalske in Slovenije ${ }^{1}$ - v skupnem prizadevanju, da bi okrepili zavest o moči in razsežnostih mitoloških vsebin v današnji Evropi in s tem pripomogli $\mathrm{k}$ boljšemu (u)videnju sodobnega sveta. Dejavnosti v okviru projekta potekajo v različnih evropskih mestih in obsegajo dramske in plesne uprizoritve in performanse, avdiovizualno in filmsko produkcijo, simpozije in znanstvene publikacije. ${ }^{2}$

Pod povezovalnim naslovom »Mit in pogled « smo zbrali šestnajst prispevkov raziskovalcev iz Španije, Francije, Italije in Slovenije, ki se $\mathrm{z}$ vprašanjem mita,

1 Koordinatorica projekta: Univerza Carlos III v Madridu, Španija. Soorganizatorji: Univerza Paris Diderot, Francija; Univerza v Ljubljani, Slovenija; Asociación ASTA, Portugalska; Artimbanco, Italija. Pridruženi partnerji: Odin Teatret, Danska; Univerza Çukurova, Turčija; Fatias de Cá, Portugalska; Círculo de Bellas Artes, Španija.

2 Dve večji akademski srečanji s široko mednarodno udeležbo sta bili od 8. do 10. aprila 2014 na Univerzi Paris Diderot in od 21. do 24. maja 2014 na Filozofski fakulteti Univerze v Ljubljani. 
mitologije in pogleda ukvarjajo z najrazličnejših perspektiv na področju humanistike (literatura, gledališče, zgodovina, arheologija, filozofija, antropologija, umetnostna zgodovina, psihoanaliza, sociologija in etnologija), in tako imamo pred sabo kar se da pestro paleto študij, ki dokazujejo, da je izbrana tema neizčrpna zakladnica tako kanonskih kot vsakič znova nepredvidljivih vsebin.

$\mathrm{V}$ posebno veselje nam je, da se je na naše vabilo k sodelovanju odzvala avtorica svetovnega slovesa in zaslužna profesorica partnerske Univerze Paris Diderot, Julia Kristeva. Za svoj prispevek k tej izdaji je izbrala 2. poglavje iz svoje monografije Visions capitales. ${ }^{3} \mathrm{~V}$ besedilu »Qui est Méduse? « (Kdo je Meduza?) z eruditskoliterarnim zamahom osvetli enega najbolj emblematičnih mitoloških - in seveda umetnostnih - motivov, povezanih z usodnim pogledom in obglavljenjem. $\mathrm{Ob}$ soočenju različnih likovnih reprezentacij Meduze pokaže, kako lahko njen s kačami oviti obraz v človekovem nezavednem sproža različne, tudi povsem nasprotujoče si odzive.

Prispevek Luz Neira se prav tako osredinja na paradoksalno moč Meduzinega pogleda, ki se je izoblikovala že v antiki. Avtorica v izčrpni študiji sledi neštetim upodobitvam Meduze $\mathrm{v}$ rimskih mozaikih, zvesto opira njihovo interpretacijo na literarno izročilo antičnih avtorjev in izriše razgiban mitološki, zgodovinski, literarni in umetnostnozgodovinski proces, $\mathrm{v}$ katerem se je Meduzin pogled, ki spreminja $\mathrm{v}$ kamen, na simbolni ravni hkrati preoblikoval tudi v apotropejskega.

Povsem drugačne, plemenite in navdihujoče lastnosti pogleda vpelje članek Marka Uršiča. Iz antike se preselimo v renesančno Italijo, ki je na novo odkrila in postavila v središče sveta skupaj s človekom tudi njegovo (nesmrtno) dušo. Avtor tako ob znamenitih primerih renesančnega slikarstva analizira izvirno prispodobo Marsilia Ficina o vsevidnem angelskem pogledu kot metafori za vseprisotni Um, h kateremu se dviga človeška duša. Um je za renesančnega filozofa »oko duše«, duša pa nosi v sebi podobe vseh reči in torej usmerja človeka k spoznanju in ljubezni. Tudi Igor Škamperle izhaja iz povezave med pogledom in spoznanjem, ko na primeru Odisejeve prigode s sirenami zoperstavlja lastnostim pogleda drugo temeljno obliko človekove čutne zaznave, sluh, in v filozofski refleksiji o poti do resnice preigrava dilemo o primatu besede oz. pripovedovanja nad podobo.

Epizode iz Homerjevega epa so bile od nekdaj tudi neizčrpen vir slikarskih upodobitev. Jure Mikuž je izbral za izhodišče svoje študije pomenljivo ilustracijo Odisejevega srečanja s Polifemom, kakor ga je upodobil slovenski modernistični slikar Marij Pregelj. Avtor v večplastni analizi nadgradi umetnostnozgodovinsko obravnavo Kiklopa kot slikarskega motiva $\mathrm{z}$ antropološkimi in psihoanalitičnimi prvinami in 
tako razkrije najgloblje vzvode, ki so Preglja vse življenje spodbujali, da se je vsakič znova vračal k liku enookega velikana.

Sledijo prispevki, ki približajo mnogoterost vlog mitoloških vsebin na pogledu najbolj neposredno, »etimološko« zavezanem področju, v gledališču. Tomaž Toporišič skozi sociološke, antropološke, kulturološke in literarne študije in analizo sodobnih uprizoritev utemeljuje, da je multikulturalizem in identiteto $\mathrm{v}$ sodobni kulturi in uprizoritvenih praksah nadomestila nova vrsta kulturne mnogovrstnosti - proces kreolizacije, tj. preplet različnih kulturnih tradicij, ki izhajajoč iz mitov, skupnih različnim bazenom, presega opozicijo med globalnim in lokalnim in velikokrat spregovori ne samo proti dominaciji, ampak tudi o pomenu marginalnosti, drugačnosti in lokalnih kontekstov.

Trije avtorji se osredinjajo na konkretne sodobne dramske predelave dveh klasičnih mitov. José Luis García Barrientos izhajajoč iz pomena pogleda in njegovih usodnih posledic v Sofoklovi tragediji Kralj Ojdip analizira izvirno igro metagledaliških, avtofikcijskih in psihoanalitičnih prvin, s katerimi je sodobni urugvajsko-francoski dramatik Sergio Blanco v drami Tebas Land ustvaril prepričljivo iluzijo resničnosti in hkrati izvirno prepletel različne zgodovinske interpretacije tega mita, Patrizia Farinelli pa na primeru aktualizacije mita o Antigoni v istoimenski drami Valerie Parrella pokaže, kako italijanska avtorica $\mathrm{z}$ uporom svoje junakinje - kršenjem prepovedi prekinitve življenja - nastavlja ogledalo kolektivni vesti in tako nadgradi prevladujočo interpretacijo tega mita kot zgleda za uporniško dejanje posameznika proti političnim oblastem s kritiko politične inertnosti, miselne rigidnosti in pomanjkanja odgovornosti posameznika in celotne sodobne skupnosti. Alejandro Rodríguez osvetli še dve moderni predelavi mita o Antigoni, eno v dramskem in drugo v poetičnoproznem besedilu španske filozofinje Maríe Zambrano, tako da ju postavi v avtoričin filozofski in avtobiografski kontekst eksila in principa ubeseditve metafore in t. i. "poetičnega razuma«.

"Literarni blok« tvorijo trije članki, ki se smiselno dopolnjujejo, saj pokažejo, kako se v sodobni književnosti prepletata tematski in formalni vidik rabe mita. Avtorici prvih dveh prispevkov vsaka $\mathrm{z}$ drugega zornega kota predstavita aktualizacijo mitološkega motiva spusta v podzemlje pri dveh izjemnih literarnih mojstrih 20. stoletja. Agata Šega vzame pod drobnogled izbrane epizode na to temo iz romana Ristanc Julia Cortázarja. Opirajoč se na teorijo Carla Gustava Junga poudari tiste med vsakdanjimi dogodki, ki vsebujejo poleg neposrednega in površinskega še globlji simbolični in arhetipski pomen in so prikazani v za Cortázarja značilni transgresivni in trivializirani obliki. Irena Prosenc obravnava lik pesnika, kakor ga v dveh delih izoblikuje Claudio Magris: $\mathrm{v}$ prvem $\mathrm{v}$ povezavi z mitom o Orfeju in Evridiki, $\mathrm{v}$ drugem pa se ta preplete še z mitoma o Argonavtih in Odiseju. Toda pri Magrisu se mit ne pojavi kot motiv, temveč 
kot osnova za odpiranje pomembnih metaliterarnih vprašanj o identiteti pripovednega glasu in z njim povezani verodostojnosti pripovedi. Margherita Cannavacciuolo pa se na filozofskih in psihoanalitičnih premisah posveča analizi dveh ženskih likov $\mathrm{v}$ novelah mehiškega pisatelja Joséja Emilia Pacheca, in ugotavlja, kako se v izgradnji odnosov do moških protagonistov ter preko pripovedne artikulacije vizualnih dinamik, ki vodijo enkrat od namišljenega pogleda $\mathrm{k}$ resničnemu, drugič pa od resničnega $\mathrm{k}$ namišljenemu, tematsko in formalno izrišeta dve različici moči Meduzinega pogleda.

Za konec smo namenili posebno pozornost osvetlitvi mitov, ki so se ohranili v slovenskem izročilu, in njihovima vlogi in moči v današnji slovenski kulturni zavesti. Zadnji trije članki torej prispevajo $\mathrm{v}$ evropsko mitološko zakladnico še lokalne mitološke motive, ki tako po obliki kot po sporočilnosti potrjujejo, da se tudi pri obravnavi nacionalne mitološke podstati gibljemo v univerzalni kulturni sferi.

Barbara Pregelj najprej predstavi izvor enega najpogostejših motivov v slovenski ljudski književnosti - Lepe Vide, mlade matere, ki zapusti dom in otroka in se znajde na španskem ali mavrskem dvoru - in nato $\mathrm{z}$ analizo različnih diskurzov, od androcentričnega in moralizirajočega prek romantičnega do feminističnega in parodičnega, sooči njegova izvorna, kanonska in sodobna subverzivna interpretativna branja. Tudi drugi lik iz slovenskega ljudskega izročila, Peter Klepec, ki ga v svojem prispevku prouči Anja Moric, se sreča z Mavri in tudi njegova zgodba je v slovenski zavesti spodbudila diametralno različne interpretacije. Telesno in socialno šibek fantič, ki s pomočjo pravljičnih sil odreši cesarstvo Turkov, je hitro prerasel iz lokalnega v nacionalnega junaka, hkrati pa je lahko tudi alegorija slovenske šibkosti v kontekstu zgodovinske podrejenosti drugim. V zadnjem prispevku Tanja Kovačič oriše segment v slovenski mitologiji, v katerem se izraža zapleten odnos človek - pes, in pokaže, kako se je oblikoval predsodek, po katerem (črn) pes v tem odnosu podobno kot v drugih simbolnih in folklornih tradicijah najpogosteje predstavlja negativne, nevarne in grozeče sile iz onstranstva.

Kot vezni člen med pogledom ustvarjalca in pogledom raziskovalca ter hkrati kot uvod v zbirko študij v osrednjem delu revije sledi besedilo s pomenljivim naslovom »Poetična pogleda Narcisa in Meduze: preoblikovanje resničnega«, ki ga je prispeval umetniški in akademski vodja projekta Crossing Stages Sergio Blanco. Avtor v dveh mitičnih pogledih par excellence ne prepozna le njune usodnosti, temveč poudari še en, veliko bolj plemenit učinek: poíesis, torej njuno zmožnost, da spremenita, preoblikujeta tisto, kar imata pred seboj, in ustvarita nekaj novega. Na podlagi subtilne analize in dialoga s klasično tradicijo utemelji vlogo umetnika, ki s svojim pogledom, v katerem odseva sebe, drugega in svet, ki nas obdaja, prav tako preoblikuje resničnost in ustvarja tisto najvišje, ki ostaja večno. 